\title{
Troubling unknowns and certainties in prostitution policy claims-making
}

\author{
Isabel Crowhurst
}

\section{Introduction}

[A]s Foucault (1980) has reminded us, non-knowing about sex typically is accompanied not by silence but by a voluble proliferation of discourses (Epstein 2006: 2).

Prostitution laws and policies, whether merely proposed or already implemented, are often based on matter-of-fact and unchallenged claims about the composition and organisation of the sex markets they aim to target, the motivations and conditions of those who operate within them, and the effects of the implementation of the regulatory norms they prescribe. In contrast, an increasing body of work in the expanding field of prostitution and sex work studies ${ }^{1}$ shows that empirical evidence pertaining to these very aspects is wanting or altogether lacking, and very difficult to gather. It is this incongruence that I am interested in exploring further in this chapter. Taking my cue from Esptein's quote above, I discuss how non-knowing about prostitution is accompanied, in policy-making in particular, not by silence or acknowledgement of unknowns in the field, but by a voluble proliferation of absolute knowledge claims. My aim is to interrogate the ways in which such claims are deemed factual and authoritative, and what the consequences of this may be.

In an effort to grapple with these issues, in what follows I take as my point of departure recent developments in prostitution and sex work studies, outlining ways in which unknowns and knowledge limitations in the field are acknowledged, approached and made sense of. I then turn to briefly contextualising the almost ostentatious display of all-encompassing knowledge in prostitution policy making, and the concurrent ignorance of uncertainties and ambiguities, as manifestations of morality politics. Further, the chapter delves deeper into the exploration of these ambivalences by taking as a case study the analysis of prostitution law proposals submitted to the Italian Parliament since 2008; here I identify various typologies of claims and discuss how they contribute to the validation of an uncompromising and all-knowing 
picture of prostitution and its governance. In the concluding section, I advance some reflections on how ignorance and the awareness of ignorance can be mobilised to engender more responsible knowledge practices in the field.

\section{'How much do we (not) know about prostitution?' Overview of an ambivalent answer}

Over the past forty years or so prostitution has become a visible and acknowledged, though not always respected, subject of social research, as reflected in the development and expansion of the field of prostitution and sex work studies (Kempadoo 2009).

Multidimensional analyses of commercial sex have emerged during this time, with studies across disciplines engaging in exploration of the complex interplay of sex, intimacy and labour in various historical, political, economic, social, and legal contexts (see, for example, Walkowitz 1980; O’Connell Davidson 1998; Levine 2003; Agustin 2007; Bernstein 2007; Cheng 2010; Scoular and Sanders 2012; Shah 2014). This body of work emphasises the diversities of women's and men's experiences in the sex industry, thereby opening up a 'more complex, nuanced and relational vision of gendered power', as compared to previously dominant approaches that explain prostitution within the dyadic model of master (superordinate powerful male) versus subject (subordinate dominated female) (Brace and O'Connell Davidson 2000: 1046). While gender analysis of the configurations of sexual commerce remains central to most recent research, the study of its intersection with other factors, such as formal and informal sex markets, laws and policies, processes of globalisation, and the wider economy, is reinforcing understandings of prostitution as a complex socially and economically constituted phenomenon. Despite this broadening of scope and analytical perspectives many scholars concede that commercial sex remains a particularly challenging area of study, and one in which research is not easily conducted. This is due to its heterogeneity and changeability, hidden and hard-to-reach populations, and the still limited research approaches available for exploring this complex landscape - factors that contribute to the persistence of gaps and unknowns in the field (Sanders 2006; Hardy, Kingston, Sanders 2010; Weitzer 2010; Berger and Guidroz 2014). Furthermore, the recent 'explosion of sex work research' (Kingston and Sanders 2010) is unevenly distributed, coming out of and focusing on geographically specific clusters - North America, Australia, New Zealand, and most, but not all, Western European countries. This is due to funds, research politics and cultures in these countries making it possible to pursue prostitution and sex work as worthy, albeit not immune from stigma, subjects of enquiry (Hammond and Kingston 2014). Due to this differential development, widely available research on specific 
contexts is often generalised as representative of and valid for all sex industries. Weitzer notes, for example, that:

Most academic studies have been conducted in nations where prostitution is criminalized and clandestine. This means that knowledge is heavily skewed in the direction of a single type: illegal sexual commerce. Much less is known about nations that have more tolerant policies and thus offer an alternative to criminalization (2014: $81)$.

As this concise overview indicates, in this dynamic and growing field of study, epistemological and ontological differences in the investigation of prostitution and sex work are being addressed (although not without difficulties), and knowledge of the complexities of commercial sex continues to grow, spurred on by new research (Kempadoo 2009). At the very same time, however, there is widespread awareness of the limitations of the breadth and depth of empirical research in this same field across the globe, resulting in many of its aspects remaining only partially explored or altogether unknown.

Scholars of the study of ignorance suggest that this paradoxical situation, whereby 'whenever new knowledge arises, the perceived amount of non-knowledge increases at least proportionally' (Gross 2007: 743), is integral to much scholarship of the twenty-first century. Uncertainty is increasingly accepted as an established feature of contemporary reflexive modernity, with the taken for granted premise that the mastery of the modern world is possible being dispelled (McGoey 2012). The vanity that the social world is all-knowable is replaced not only by an awareness that accruing new knowledge compounds ignorance, but also by a readiness to come to terms with decreased control over what is, and what can be, known (McGoey 2012). New ways in which ignorance and unknowns can be approached as valuable resources are thus becoming apparent: 'intentionally tenuous, strategically uncertain claims are increasingly recognised for what they are: critical sources of political power' (Gross and McGoey 2015: 5). Research itself is shifting away from 'traditional research strategies of reducing ignorance towards a greater capacity to cope with ignorance' (Gross 2007: 745), and towards a deeper exploration of the many different ways in which ignorance is harnessed for political and economic advantage (McGoey 2012). 
In the field of sex work and prostitution studies, for example, efforts are focused upon developing participatory methodological approaches that contribute to accessing a richer understanding of sex work and its complexities (see O'Neill 2001, 2010; Shaver 2005; Abel, Fitzgerald and Brunton 2010; Dewey and Zheng 2013). These efforts diverge from the more traditional in that they are not underpinned by an imperative to acquire knowledge at all costs with a 'smash and grab' mentality (Sanders 2006). By moving away from a dismissive and pejorative conceptualisation of unknowns as voids or omissions to be filled or rectified acknowledgement of ignorance in this area of study is not necessarily experienced as regrettable or harmful. Instead it can be viewed as contributing positively to epistemic responsibility and the development of more appropriate research practices vis-à-vis oppressive knowing and methodologically flawed and ethically problematic research. Furthermore, unknowns are not only approached from a methodological perspective, but are also explored as epistemological products, with questions asked about what, how and why certain silences and absences are produced, and about why and how 'often simultaneously, other matters are prominently talked about, are regarded as known, and fill a presence' (Rappert and Balmer 2015: 333). In addressing these points, warnings have been raised that research objects, research findings and unknowns in this ideologically and politically charged field can lend themselves to a utilitarian and selective use which 'serves to maintain and legitimate particular definitions of "the problem" that must be addressed' (Phoenix 2009: 163).

Indeed, to return to the incongruence that is central to this chapter, the discernment that much still remains unknown about the composition and organisation of the sex industry and the effects of policies targeted at its governance is often ignored. This stands emphatically in contrast to the many alleged 'facts' and 'certainties' commonly proclaimed with respect to these very aspects by politicians, policymakers and public administrators in supporting their prostitution policy approaches ${ }^{2}$. In explaining this predicament, Wagenaar and Altink (2012) advance the idea that filling in knowledge gaps, or supplanting whatever supported evidence is available, with dubious knowledge claims is a characteristic of morality politics, of which prostitution policy is a glaring example. Morality politics, they explain, is constituted by policies 'that are characterised by seemingly irresolvable conflict over deep values' (Wagenaar and Altink 2012: 282). While the latter 'are at stake in every policy' (Wagenaar and Altink 2012: 282), morality politics is characterised by deep, intractable and irreconcilable hostilities which tend to be centred on social problems of a particularly 'thorny 
nature' (Boghenschneider and Corbett 2010), such as prostitution. Such hostilities restrict open debate and foreclose the possibility of both engaging in collaborative problem solving and designing effective and reasonable public policies (Wagenaar and Altink 2012).

Moreover, in cases of moral politics, everybody feels they have 'something worthwhile to say about the issue or phenomenon at hand' (Wagenaar and Altink 2012: 283). The latter, in this case prostitution, no matter its complexity, is claimed to be owned and expertly known in its entirety, such that it can be successfully tackled, resolved or regulated with no need to refer to more informed sources of technical authority or evidenced research. In this context, laws and policies, actual or proposed, do not require stringent justification - what validates them is the crusade-like emotional charge of the claims that accompany them, often used 'as a vehicle for a larger moral cause' (Wagenaar and Altink 2012: 283). These claims, as discussed in the next section, tend to follow a script that runs along these lines: 'a great wrong lives among us, here are some representative examples, it is imperative that we act forcefully and immediately' (Wagenaar and Altink 2012: 284), usually leading to policy interventions whose effects - unrealistic as they may be - are professed to be fully anticipated. In sum, what counts in morality politics, Wagenaar and Altink maintain, is the "symbolism of heroic measures', rather than any concern for the applicability of the measures proposed, or for the validity of the assumptions underpinning them.

\section{Validating 'facts' and 'certainties' in prostitution policy claims-making}

In order to examine more closely how prostitution policy claims are advanced, validated and justified in the epistemic contexts outlined above, in this part of the chapter I analyse the prostitution bills presented by Italian Members of Parliament (members of the Chambers of Deputies and of the Senate of the Republic) in the current (2013 - present) and previous legislatures (2008 - 2013). The focus on Italy both reflects my long-standing interest in and work on the governance of prostitution in the country (see Crowhurst 2012a, b), and sheds light on processes of 'knowledge'-making in prostitution policies that can be further applied to other contexts, both in Europe and beyond.

A total of thirty-nine prostitution bills have been submitted to the Italian Parliament in the past eight years. This large number reflects the long-felt, yet frustrated, need to amend current Italian national prostitution law, which has been in place since $1958^{3}$. Italy: the never-ending debate, the title of Daniela Danna's (2004) analysis of the politics of prostitution in Italy, has become a phrase emblematic of the interminable and inconclusive discussions that have been 
taking place in the country over the past decades about the need for a new prostitution policy to replace the current, outdated one. Even the proposals analysed here, although they have contributed to inflaming these debates, are unlikely to pass into law. Some put forward systems of regulation that are too impractical, or too politically unrealistic and ambitious, in the current climate to advance through the many stages of the legislative process. Others, including the one submitted on behalf of the government in 2008, progressed to the point of parliamentary approval, before a change in the political climate resulted in its addition to the list of highly publicised, but doomed, prostitution bills (Crowhurst 2012b).

These unsuccessful proposals can be compared with what Povinelli calls quasi-events - these, unlike actual events, 'never quite achieve the status of having occurred or taken place. They neither happen nor not happen' (2011: 13), and for this reason, they are apprehended, grasped and accepted almost without reflection (Povinelli 2011: 13). Because they end up in the 'pile' of proposals that never made it into law, their role in contributing to the accumulation of partial 'knowledge' on prostitution is overlooked. On the other hand, events, such as bills that have actually passed into law, by virtue of our awareness of their having happened 'necessitate ethical reflection and political and civil engagement', which may elicit scrutiny and critical appraisal (Povinelli 2011: 13-14). In other words, even if they do not 'happen', i.e. pass as law, these proposals contribute to bringing into being an often taken for granted reductionist understanding of the 'problem of prostitution' - one which assumes comprehensive knowledge of its causes, composition and organisation, and deems the 'problem' solvable with policies whose effects are claimed to be known with certainty. It is this uncompromising and simplistic picture of prostitution that becomes the subject of public and political debate, thus reinforcing its dominance and presumed veracity. As Agustin notes in her analysis of projects to improve the governance of commercial sex, if the proponent of a plan excludes the messy complexities and ambiguities from the subject, the problem tackled appears 'more feasible than it actually is, [and] it becomes easier to make the plan appear reasonable' (2008: 76). However, radical simplifications often come at the cost of contextual understanding (Quick and Broome 2015). Indeed, evidence of the complexities and ambiguities of the Italian sex industry gathered over the years by the many non-governmental organisations active in the field, and acknowledgement of the gaps in knowledge that still remain, are conveniently ignored in the majority of the bills analysed (Crowhurst et al., forthcoming). 
The bills, following a standard format, include the text of the law, preceded by introductory explanatory memoranda of varying lengths that contextualise the rationale of the proposed law. Here, a dramatic picture of prostitution in the country is often presented - the 'great-evilamong-us' scenario previously mentioned - with an emphasis placed on the negative effects that prostitution has on the wellbeing and daily lives of 'good' citizens. The harrowing landscape portrayed is compounded by visions of the unstoppable invasion of public spaces by 'foreign prostitutes', the resulting collapse of morals and values, the threat that this brings to the 'Italian family', an impending health epidemic, and the expansion of violent criminal networks who exploit sex trafficking. It is in these introductory memoranda that various claims to knowledge are advanced as to what constitutes the 'nature' of prostitution, its extent, the reasons for getting involved in it, the need for a particular type of policy intervention, and the impact the latter will have. In the next section I examine three typologies of such claims: commonsensical typifications on the inevitability of the 'oldest profession', self-evident absolutes, and quantifications of the phenomenon of prostitution.

\section{The oldest common sense on prostitution}

Some of the bills analysed contained the statement, with some variations, that prostitution is 'the oldest profession in the world', followed by the more or less explicit sequitur: 'prostitution has always existed, and therefore it will always exist'. This can be characterised as a commonsensical claim, one that is based on shared beliefs that are supposed to 'represent the distilled truths of centuries of practical experience', and therefore consensually assumed to be incontrovertible (Lawrence 1982: 48). In essence, a matter of common sense is expected to make sense no matter where or when its 'sense' actually originated: its tenets are assumed to be so taken for granted and banal that they 'go without saying'. Validated by their unwavering transmission through time, commonsensical claims become 'truisms about which all sensible people agree without argument or even discussion', whether they are about 'principles of amount, difference, prudence, cause and effect' (Rosenfeld 2011: 1).

In a recently presented bill, for example, Deputy Vargiu and colleagues begin their report by stating that 'the history of prostitution is as old as the world, and equally old is the polemic about whether it should be legitimate for men and women to sell their bodies' (Vargiu 2014: $1)^{4}$. Prostitution and debates surrounding what to do about it are presented as based upon this common sense and are thus unquestionably inexorable, thereby eluding the need for further explanation of why prostitution exists, how it exists now compared to how it may have been 
organised historically, and the reason for its inexorability. In this respect, common sense notions about prostitution's timelessness and trans-historical character contribute to the reification and universalisation of it as a unified category, 'by treating all instances of the exchange of sex for money as different cases of the same thing' (Karras 1998: 10, quoted in Mattson 2015: 212). Deputy Vargiu et al. also state that common moral values prescribe in absolute terms 'that selling one's body for remuneration is a discreditable act', and it cannot be culturally accepted that anyone would voluntarily choose to do so (2014: 1). In light of this, the Deputies reject the 'ultra liberal position' of those who champion the free choice argument, and insist that their law proposal remains anchored in the belief that, in a civil and evolved society, sexual acts should entail an intimate connection between people and should not be subjected to any commercial market value. Given the bill's identification of prostitution as a deplorable, yet inevitable, phenomenon, it would seem logical to expect a proposal for the criminalisation of prostitution. Quite the contrary: Deputy Vargiu et al. advocate for the introduction of a system of strictly regulated outdoor and indoor prostitution. They explain that this policy choice is motivated by the need 'to deal pragmatically with the problem, while respecting different convictions, and without the interference of old prejudices' (Vargiu 2014: 2). A regulationist approach, they comment, is the best solution for guaranteeing the dignity of the person, protecting the social order and public health, and allowing the state to take advantage of the 'small hidden treasure' that can be unearthed through the fiscal taxation of commercial sex (Vargiu 2014: 5).

The relationship established in Deputy Vargiu et al.'s bill, between the inexorability of prostitution and the pragmatic need to regulate it, is also presented in two other bills: one submitted by Senator Malan and the other by Senator Lauro. Senator Malan states that his personal view on prostitution, like that of many others, is negative. Nevertheless, because prostitution has always been in existence in all societies, 'even when it was opposed with severe punishments and absolute moral condemnation, it would be absurd to think that a law may get rid of it' (Malan 2014: 2). Similarly, in his bill Senator Lauro affirms that 'the legislator cannot [...] evade the duty to discipline "the oldest profession in the world" which, most likely, no criminal law will ever be able to eliminate' (Lauro 2010: 4). Both proponents acknowledge that prostitution is a social and moral problem, but also an ineradicable one, and they therefore call for the criminalisation of outdoor prostitution - thus allegedly putting an end to the exploitation and moral threat that it generates - and for the fiscally profitable regulation of the indoor sex industry. 
In spite of the contradictions found in the statements advanced in these bills, the rationale for the policy approach proposed is sustained by their assertion about the inevitability of prostitution, a practice that has always existed - as the 'oldest profession' in the world - and will therefore always exist. The proposers acknowledge, and agree in principle with, the denunciation of prostitution as a problematic practice, thus avoiding alienating those who hold this perspective. However, they dismiss the viability of an abolitionist policy by appealing to the commonsensical inevitability of prostitution: there is simply no escaping it, which warrants a pragmatic, not a morality-inspired, approach. Within this reasoning, the need for a more rigorous analysis and complex understanding of the phenomenon is foreclosed, and its controlled and strict regulation is authoritatively offered as the best solution to pursue in the interest of the common good (and of the state's fiscal revenues).

These reductionist arguments and simplifications facilitate the passing of certain policy approaches as the 'logical', most pragmatic solutions, and, in doing so, also function to conceal the ideological premises underpinning them (Hall in Lawrence 1984). In this respect, although it is not the aim of this chapter to discuss the broader contextual politics of the bills analysed, it should be noted that the policies put forward - whether the criminalisation of street prostitution and regulation of the indoor sector, or the regulation of both - perpetuate the construction and treatment of those who sell sex as forever problematic social subjects. Because of this, the state has a duty to police and monitor those involved in prostitution closely to ensure that their activities do not encroach upon the lives of 'normal' citizens who do not contravene norms of acceptable sexual behaviour. The ideological underpinning of this bio-political rationality is not a novelty, having been widespread in many European countries since the mid-nineteenth century ${ }^{5}$ (Scoular 2015). What is new and worth noting here, however, is the use of a market morality to justify taking advantage of the profitability of the sex industry, which, if maintained under strict state control, can contribute to an economy under strife.

\section{Self-evident absolutes}

In addition to the use of common sense to validate knowledge claims about prostitution, selfevident absolutes are frequently found in the proposals analysed, i.e. claims that, uttered as self-sustaining truths, function as tautologies: by virtue of their (supposed) self-evidence they require no agreement, evidenced demonstration, or validation. They differ from common 
sense because their legitimation does not rest on a general consensus and presumed transhistoricity. These are mostly unilateral propositions, asserted and validated dogmatically by a single individual or a small number of proposers, who, with respect to the bills examined, appeared to have a comprehensive and undoubting knowledge of how prostitution is organised and what the best policy approach for dealing with it is.

Examples of self-evident absolutes are statements made about the differing 'nature' of indoor and outdoor prostitution, particularly in relation to how exploitative each can be. Some proposals state that street prostitutes in Italy always operate in conditions of complete enslavement, exploited by criminal networks, whereas those who operate in indoor prostitution freely choose to engage in commercial sex and do so in better working conditions $^{6}$. Senators Maturani et al., for example, contend that while street prostitutes are generally perceived as an offensive presence, public opinion lacks consideration of the fact that 'those who prostitute themselves in the street never do so in a condition of freedom. In other words, in the street we find women who are at a minimum exploited, or even held in complete slavery' (Maturani 2015: 3, emphasis added). Based on this consideration, the proposers continue, it is not possible to ignore 'that those who freely decide to sell their body are not present on the streets, but operate in their own flats, or maybe hotels, whereas the street remains in the hands of those who organise the forced exploitation [of prostitution]' (Maturani at al. 2015: 3). Other proposals include a similar claim; for example, Carfagna et al. affirm that 'it is in public spaces that the most severe criminal acts aimed at sexual exploitation are carried out' (Carfagna 2008: 3), and based on this absolute statement call for the criminalisation of outdoor prostitution, and the regulation of indoor commercial sex.

Other instances of the use of self-evident absolutes in these bills are the assertions made, all involving obscure and unexplained causalities, about the best approach needed to deal with prostitution in the Italian context. These can be observed in Senators Alberti Casellati et al.'s proposal, where it is advanced that 'the absence of [prostitution] regulation [...] inevitably determines its expansion', followed by the statement that 'neo-regulationism is [...] the best model to allow finding a balance between the needs of those who prostitute themselves and the needs of the community' (Alberti Casellati 2014: 2, 3, emphasis added). Similarly, Deputies Gigli et al., following a brief overview of what they identify as the three main models of prostitution regulation (prohibitionism, abolitionism and regulationism), state that, 'among the models presented [...] after a careful analysis of their effects and after a 
comparison of the statistics available about them, the so-called neo-prohibitionist, also called the Swedish model, is undoubtedly the best suited to the needs of Italian society' (Gigli 2014: 2, emphasis added) - a conclusion reached without any explanation. Also lacking any elucidation is Senators Serra et al.'s claim that the criminalisation of outdoor prostitution and the strict regulation of commercial sex in private flats will facilitate the arrest of those who exploit prostitution, while at the same time drastically reducing the number of irregular migrants and minors engaging in commercial sex (Serra 2008: 3). A final example of the use of self-evident absolutes is Senator Stiffoni's bill. In his opening statement he proffers: 'we are powerlessly witnessing a "white slave trade" which happens under our own eye, [women are] exploited as slaves and without being subjected to any health checks, thus [carrying] the danger of serious infections or deadly diseases' (Stiffoni 2008: 2). The Senator maintains that threats to both the morality and health of the Italian population will be addressed and solved through the introduction of a law that will regiment and standardise interactions between clients and prostitutes. The latter will have to demand payment for sexual services before these are actually provided, and during this preliminary transaction they will have to show their client a medical certificate stating that 'there are no dangers of infection in carrying out sexual services' (Stiffoni 2008: 2). Undercover police forces will regularly be deployed to act as clients and check that these procedures are duly followed, with incarceration and deportation (for non-Italian citizens) acting as penalties for breaking this law. Having thus 'solved' the problem of the spreading of 'infections and diseases', the Senator also emphasises that the regular health checks that prostitutes will have to undergo, by law, will function as an important instrument for the police to 'contact in a discreet manner people who sell sex and receive from them confidential information and complaints' (Stiffoni 2008: 2), thus contributing to eliminating sexual exploitation.

The undoubting authority with which these measures are presented, no matter how far removed from the lived realities of selling and purchasing sex they are, reinforces the comforting belief that the 'problem' of prostitution is comprehensively known and can easily be solved, and that social order will thus be maintained. By ignoring unknowns, ambivalences and complexities relating to this matter, the 'knowers' present themselves as epistemically superior (Logue 2011) and in control - factors that both contribute to solidifying their sense of power and are expected if they are to remain in such a position of power. 
Further strengthening the matter-of-factness of the claims advanced in these bills is the frequent quotation of numerical figures. The latter are mostly used to quantify how profitable the sex industry is, the number of those who buy and sell sex in the country, and how many of the latter are women, minors, 'foreigners', and victims. With very few exceptions, there is no mention of the sources of the data cited. Senator Serra's report, for example, refers to the following figures: 'in Italy prostitutes are 70,000, excluding transgender and transvestites'; the majority of street prostitutes are foreign women (20\% of whom are minors); and victims trafficked into the Italian sex industry are between 19,000 and 26,000 each year (2008: 2). Prestigiacomo, on the other hand, claims that the number of "foreign prostitutes "exported" to Italy during the past few years and forced to prostitute themselves on the streets' is 25,000 (Prestigiacomo 2008: 2, emphasis added). Other variations concern how profitable the sex industry is in Italy, with the yearly turnover amounting to: over one billion Euro (Serra 2008), over 2 billion Euro (Foti 2008), 5 billion Euro (Turco 2015), or many billions (Marturani 2015). Some bills state that there are currently 9 million men paying for sex in the country, with others claiming that 9 million men in Italy have paid for sex at least once in their lives (Romano et al. 2015). This number is rather outdated, but has been recirculated unchanged since it was first cited in a 1996 study based on research conducted on street sex work only (Crowhurst et al. forthcoming).

Contextual details such as the latter are not mentioned in the reports. This contributes to a process of simplification, which entails the loss of depth and analytical complexity, while at the same time unreliable, incomplete, or context-specific data become popular and generalised via their public repetition, eventually acquiring the status of timeless 'fact' (Quick and Broome 2015). Another example of this is Gigli et al.'s (2014) use of statistics originally presented in a 2011 academic article on the effectiveness of the neo-abolitionist policy regime introduced in Sweden in 1999 (see Waltman 2011). In their introductory report, the Deputies cite in detail the study's figures, which show a marked decline in the number of prostitutes and clients, as a result of the passing of the Swedish law. These data, they conclude, show that the Swedish approach 'is undoubtedly the system to follow' (Gigli 2014: 3), and they propose a similar one in their bill. As Skilbrei and Holmström (2013) have carefully explained, the reliability of the figures reported in the 2011 study is questionable as the high differentiation of prostitution markets in Sweden poses a challenge to any attempt to estimate their size. Moreover, the recirculation of these numbers is problematically used to explain an unsophisticated causality between criminal justice policies and how people behave in the 
context of the sex industry, without taking into account the many other relevant and contextspecific factors that play a part in explaining any changes in the composition of commercial sex (Skilbrei and Holmström 2013).

As the comments above show, the politics of numbers in this field (and related ones) has been a subject of criticism in recent scholarship and policy debates. One aspect that has been emphasised is how the lack of interest in 'getting numbers right' does not hinder their use, invalidated by egregious flaws as they may be (Wagenaar and Altink 2012). Indeed, numbers, accurate or not, have the considerable political appeal of providing the otherwise elusive 'evidence' base that helps further validate 'knowledge' claims (Gallagher 2014). As Poovey (1998) explains, numbers have come to epitomise the 'modern fact': they have become the bedrock of systematic knowledge. Numbers are construed as superior epistemological units, because they are not viewed as interpreting reality - a process that is seen as liable to subjective bias - rather, they are assumed to accurately and truthfully describe it. They are believed to be pre-interpretive or even non-interpretive, even though, of course, they are themselves interpretations, which are embedded in and reflect particular epistemological and ontological perspectives (ibid.).

\section{From all-encompassing 'knowledge' to the value of ignorance}

The bills analysed in this chapter display an uncompromising and all-encompassing 'knowledge' of prostitution, and a simplistic and manageable picture of its composition, organisation and governance. As I have suggested, this 'knowledge' is constituted through the use of typologies of claims - common sense, self-evident absolutes, and various quantifications of prostitution - that assign factual and descriptive value to the assertions made. Legitimised by the assumed truthfulness of the latter, the proposers exempt themselves from explaining and justifying how they actually know about prostitution, its socio-demographics and markets, and how they can be so certain about the effects their policies will have. Partial and inaccurate as some (or all) of the claims analysed may appear, or how completely devoid of any evidenced or logical explanation they may be, they nevertheless are uttered and often accepted as 'simply descriptive statements about how things are (i.e. must be)' (Hall, in Lawrence 1984: 47). In this respect, even impractical or improbable bills, as quasi-events, need to be seriously considered within prostitution and sex work studies because of the role they have in reinforcing ad hoc constructions of 'the problem of prostitution', mostly dictated by political priorities, and 
often also ideological concerns. These constructions, as reproduced in political and public debates, become naturalised as hegemonic, denying and disavowing the claims and critical voices of whose who point out their limitations and who strive to present an alternative, more nuanced, but also less certain picture of the phenomenon. In other words, by extending Rosenfeld's considerations on common sense, these proposals and the 'knowledge' they convey work as an unspectacular but pervasive instrument of censorship that excludes outlying voices and limits the parameters of public debate (2011). 'The end result is $[\ldots]$ the replacement of legitimate intellectual strife with knee-jerk consensus' (Rosenfeld 2011: 14).

The alarming tones used in the proposed laws examined also suggest that they are produced in response to a perceived time of crisis in the country. The hype, fears and urgency created around prostitution need to be accompanied by a prompt display of confidence and ownership of a sense of control - both confidence and control, illusory as they may be, convey a sense of direction and stability while assuaging those public anxieties mounting around this 'problem'. Given the ominous landscape portrayed, it would be unsustainable to respond to this impending threat with an admission of ignorance along these lines: we know too little about prostitution and its organisation to be able to predict the effects that any policy will have, or to have an informed understanding of the best way of managing it, and therefore time needs to be spent on researching the phenomenon more comprehensively. In this epistemic context, it is knowledge, or the pretence to it, that increases one's political leverage and power (Gross and McGoey 2015), while ignorance of ignorance becomes a strategic form of not knowing that is used to protect power and is deployed, consciously or not, to avoid dealing with the vulnerability of unknowns and uncertainties (Logue 2013).

Is it possible, however, to challenge the predicament of epistemic unaccountability presented here, and which is so widespread in prostitution policy claims-making more generally? In what follows, and by way of conclusion, I elaborate further upon the use of ignorance to offer some reflections on possible alternatives that might trouble the pervasive use of problematic 'certainties' in prostitution policy claims-making. When, at the outset of this chapter, I referred to Epstein's powerful claim that 'non-knowing about sex is not accompanied by silence, but by voluble discourses', I did not wish to endorse silence as the alternative to these 'voluble discourses' (neither does Epstein). Not doing anything, as a result of non-knowing 
about prostitution, is also not what I propose here, and nor do I call for a rush to "smash and grab' 'real' knowledge and 'true' facts. Rather, I suggest returning to the points advanced earlier about developments in prostitution and sex work studies, as these can shed light on productive re-evaluations of processes of knowing and not-knowing in the field. As mentioned, in this expanding body of work, acknowledgement of ignorance and of limited knowledge on the complexities of the sex industry and those involved in it has not entailed an arrested development in research on prostitution and sex work. On the contrary, this awareness has functioned as a generative force, stimulating enhanced epistemological accountability and ethically responsible research, through the development of new methodologies and objections to myths, assumed conventions, absolutes and self-evident claims, as well as strategic uses of silences and of unknowns. Challenging the traditional identification of ignorance as a problem and of knowledge at all costs as its solution, has allowed for the identification of a positive and emancipatory role for ignorance (Townley 2009), where ambiguity, ambivalence and unknowns can be mobilised against dogmatic certainties and the comfort of illusory, simplified realities. Ignorance has functioned as a force towards wanting to know better rather than to not-know or make known (Logue 2013).

In concluding their discussion of morality politics and prostitution, Wagenaar and Altink (2012) present a number of conditions to consider in transforming the fraught realm of prostitution policy. These include: the need for more awareness amongst policy makers and policy enforcers of the effects of ideology on the understanding of prostitution and its contexts; the creation of better trained and more experienced administrators specialising in prostitution policy; the continued cultivation of patient and rigorous empirical research in the field; and an openness to collaborative governance, enabling dialogue with and participation of sex workers in research and policy making. To this list, I suggest adding the acknowledgement of epistemic vulnerability, as Logue (2013) puts it, as a further potential route out of the well-established and dangerous depths of knowledge-fabrication that are so common in the context of morality politics. Seeking out ignorance and unknowns, and especially so 'in those places where we are certain of knowledge' (Logue 2013 : 54), can be a valuable epistemological tool for stimulating curiosity, rather than fear, of unknowns, even when they are harnessed strategically and commodified for political or ideological uses (McGoey 2012). By slightly adapting Townley's (2009: 39) words, if we can be blinkered by knowledge, then perhaps ignorance, and awareness of ignorance, can broaden our view. 


\section{References}

Abel, G., Fitzgerald, L. and Brunton, C. (2010). Christchurch School of Medicine study: Methodology and methods. In G. Abel, L. Fitzgerald and C. Healy with A. Taylor, eds, Taking the crime out of sex work: New Zealand sex workers' fight for decriminalisation. Bristol, UK: Policy Press, pp. 159-172.

Agustin, L. (2007). Introduction to the cultural study of commercial sex. Sexualities, 10(4), pp. 403-407.

Agustin, L. (2008). Sex and the limits of Enlightenment: The irrationality of legal regimes to control prostitution. Sexuality Research and Social Policy, 5(4), pp. 73-86.

Alberi Casellati, M.E. (2014). Disegno di legge. Norme in materia di prostituzione. DDL n. 1379 (6 $6^{\text {th }}$ March 2014). Senato della Repubblica.

Berger, M. T. and Guidroz, K. (2014). Researching sexuality: The politics-of-location approach for studying sex work. In: C. R. Showden and S. Majic, eds, Negotiating sex work (eds). Chicago: University of Minnesota Press, pp. 3-30.

Bernstein, E. (2007). Temporarily yours. University of Chicago Press: Chicago.

Boghenschneider, K. and Corbett. T. J. (2010). Family policy: Becoming a field of inquiry and subfield of Social Policy. Journal of Marriage and Family, 72(3), pp. 783-803.

Brace, L. and O'Connell Davidson, J. (2000). Minding the gap: General and substantive theorizing on power and exploitation. Signs, 25(4), pp. 1045-1050.

Carfagna, M. (2008). Disegno di legge. Misure contro la prostituzione. DDL n. 1079 (6 ${ }^{\text {th }}$ October 2008). Senato della Repubblica.

Cheng, S. (2010). On the move for love. Philadelphia: University of Pennsylvania Press.

Crowhurst, I. (2012a). Caught in the victim/criminal paradigm: Female migrant prostitution in contemporary Italy'. Modern Italy, 17(4), pp. 1-14. 
Crowhurst, I. (2012b). Approaches to the regulation and governance of prostitution in contemporary Italy. Sexuality Research and Social Policy, 9(3), pp. 223-232.

Crowhurst, I., Testai, P., DiFeliciantonio, C. and Garofalo-Geymonat, G. (forthcoming). 'A tale of resilient laws and whimsical governance: prostitution policy in Italy'. In: H. Wagenaar and S. Jahnsen, eds, Prostitution Policy in Europe. Routledge.

Danna, D. (2004). Italy: The never ending debate. In: Outshoorn, J. ed, The politics of prostitution: Women's movements, democratic states, and the globalisation of sex commerce. London: Cambridge University Press, pp. 165-184.

Dewey, S. and Zheng, T. (2013). Ethical research with sex workers. New York: Springer.

Espstein, S. (2006). The new attack on sexuality research: Morality and the politics of knowledge production. Sexuality Research and Social Policy, 3(1), pp. 1-12.

Foti et al. (2008). Proposta di legge. Norme contro la pratica e lo sfruttamento della prostituzione. DDL n. 156 (29 $9^{\text {th }}$ April 2008). Camera dei Deputati.

Gallagher, A. (2014). Human trafficking: From outrage to action. OpenDemocracy (9/10/2014). [online] Available at: https://www.opendemocracy.net/5050/annegallagher/human-trafficking-from-outrage-to-action [Accessed January 15th 2016]

Gligli et al. (2014). Proposta di legge. Introduzione dell'articolo 602-quinquies del codice penale, concernente il divieto dell'acquisto di servizi sessuali, e alter norme in materia di prostitutione. DDL n. 2503 ( $1^{\text {st }}$ July 2014). Camera dei Deputati.

Gross, M. (2007). The unknown in process: Dynamic connections of ignorance, nonknowledge and related concepts. Current Sociology, 55(5), pp. 742-759.

Gross, M. and McGoey, L. (2015). Routledge handbook of ignorance studies. London and New York: Routledge. 
Hammond, N. and Kingston, S. (2014). Experiencing stigma as sex work researchers in professional and personal lives. Sexualities, 17(3), pp. 329-347.

Hardy, K., Kingston, S. and Sanders, T. (2010). New sociologies of sex work. Farnham: Ashgate.

Karras, R. M. (1998). Common women: Prostitution and sexuality in medieval England. Oxford: Oxford University Press.

Kempadoo, K. (2009). Prostitution and sex work studies. In: P. Essed, T. Goldberg and A. Kobayashi, eds, A companion to gender studies. Malden, MA: Blackwell, pp. 255-265.

Kingston, S. and Sanders, T. (2010). New sociologies of sex work. Farnham: Ashgate.

Lauro (2010). Disegno di legge. Norme in materia di regolamentazione e controllo della prostituzione. DDL n. 2460 (17 $7^{\text {th }}$ November 2010). Senato della Repubblica.

Lawrence, E. (1984). Just plain common sense: the 'roots' of racism. In: Centre for Contemporary Cultural Studies, Birmingham University, eds, The empire strikes back. London: Hutchinson \& Co.

Levine, P. (2003). Prostitution, race and politics. New York and London: Routledge.

Logue, J. (2013). The politics of unknowing and the virtues of ignorance: toward a pedagogy of epistemic vulnerability. Philosophy and Education, pp. 53-62.

Malan, L. (2014). Disegno di legge. Delega al Governo per la disciplina e la tassazione della prostituzione. DDL n. 1351 (28 ${ }^{\text {th }}$ February 2014). Senato della Repubblica.

Maluccelli, L. (2014). 'Pressioni globali, misure locali':La prostituzione di strada nella provincia italiana. $\mathrm{PhD}$ thesis, University of Nottingham.

Malucelli, L. and Martini, R. (2002). I sindaci e le ordinance: Azioni contro la prostituzione su strada. Aspasia: Bologna. 
Mattson, G. (2015). The modern career of 'the oldest profession' and the social embeddedness of metaphors. American Journal of Cultural Sociology, 3(2), p. 191-223.

Maturani, G. (2015). Disegno di legge. Disciplina dei reati connessi con il fenomeno della prostituzione e misure di integrazione sociale. DDL n. 1838 (25 ${ }^{\text {th }}$ March 2015). Senato della Repubblica.

McGoey, L. (2012). Strategic unknowns: Towards a sociology of ignorance. Economy and Society, 41(1), pp. 1-16.

McKeganey, N. and Barnard, M. (1996). Sex work on the street: Prostitutes and their clients. London: Open University Press.

O’Connell Davidson, J. (1998). Prostitution, power and freedom. Cambridge: Polity Press

O'Neill, M. (2010). Cultural criminology and sex work: Resisting regulation through radical democracy and participatory action research (PAR). Journal of Law and Society, 37(1), pp. 210-232.

Phoenix, J. (2009). Regulating sex for sale. Bristol: Policy Press.

Pitcher, J. Campbell, R., Hubbard, P., O’Neill, M. and Scoular, J. (2006). Living and working in areas of street sex work. Bristol: Polity Press.

Poovey, M. (1998) A history of the modern fact. Chicago: The University of Chicago Press.

Povinelli, E. (2011). Economies of abandonment. Durham and London: Duke University Press.

Prestigiacomo et al. (2008). Disegno di Legge. Disposizioni in materia di prostitutzione DDL n. 3826 . 
Quick, L. and Broome, A. (2015). The politics of numbers: The Global Slavery Index and the marketplace of activism. OpenDemocracy. [online] Available at:

https://www.opendemocracy.net/beyondslavery/joel-quirk-andré-broome/politics-of-numbersglobal-slavery-index-and-marketplace-of-ac [Accessed 20th February 2016]

Rappert, B. and Balmer, B. (2015). Ignorance is strength? Intelligence, security and national secrets. In: M. Gross and L. McGoey, eds, Routledge international handbook of ignorance studies. Abingdon: Routledge, pp. 328-337.

Rosenfeld, S. (2011). Common sense: A political history. Cambridge, MA: Harvard University Press.

Sanders, T. (2006). Sexing up the subject: Methodological nuances in researching the female sex industry. Sexualities, 9(4), pp. 449-468.

Scoular, J. (2015). The subject of prostitution. Abingdon: Routledge.

Scoular, J. and Sanders, T. (2010). Regulating sex/work. From crime control to neoliberalism? (Special Issue) Journal of Law and Society, 37(1).

Serra, A. (2008). Disegno di legge. Norme in materia di prostituzione. DDL n. 1093 (7 ${ }^{\text {th }}$ October 2008). Senato della Repubblica.

Shah, S. (2014). Street corner secrets. Durham and London: Duke University Press.

Shaver, F. M. (2005). Sex work research. Methodological and ethical challenges. Journal of Interpersonal Violence, 20(3), pp. 296-319.

Skilbrei, M. and Holmström, C. (2013). Prostitution policy in the Nordic regions. Aldershot: Ashgate.

Stiffoni, P. (2008). Disegno di legge. Misure contro lo sfruttamento della prostituzione e in materia di controlli sanitari. DDL n. 756 (1th June 2008). Senato della Repubblica. 
Townley, C. (2009). Towards a revaluation of ignorance. Hypathia, 21(3), pp. 37-55.

Turco, T. (2015). Proposta di legge DDL n. 3180 ( $8^{\text {th }}$ September 2015). Camera dei Deputati.

Vargiu, P. (2014). Proposta di legge. Disposizioni per la disciplina dell'esercizio della prostituzione, anche attraverso applicazioni o servizi telematici. DDL n. $2788\left(20^{\text {th }}\right.$ December 2014). Camera dei Deputati.

Walkowitz, J. (1980). Prostitution and Victorian society: Women, class, and the state. Cambridge, England, New York: Cambridge University Press.

Wagenaar, H. and Altink, S. (2012). Prostitution as morality politics or why it is exceedingly difficult to design and sustain effective prostitution policy. Sexuality Research and Social Policy, 9(3), pp. 279-292.

Waltman, M. (2011). Prohibiting sex purchasing and ending trafficking: The Swedish prostitution law. Michigan Journal of International Law, 33(1), pp. 133-157.

Weitzer, R. (2010). The mythology of prostitution: Advocacy research and public policy Sexuality Research and Social Policy, 7, pp. 15-29.

Weitzer, R. (2014). Researching prostitution and sex trafficking comparatively. Sexuality Research and Social Policy, 12(2), pp. 81-91.

\footnotetext{
${ }^{1}$ The use of 'prostitution and sex work studies' reflects the terminology adopted - most commonly either sex work or prostitution - in different scholarships globally.

${ }^{2}$ As Weitzer notes, the use of authoritative, yet partial, knowledge claims regarding sex work extends well beyond the political realm, and has been championed by 'a group of influential activists, organisations, and some academics who regard the sex industry as a universally harmful institution' and base their claims on 'self-evident, absolute principles' that are not evidence based (2010:15). ${ }^{3}$ Twenty-four policy proposals were submitted during the previous legislature (2008-2013), and fifteen have been submitted during the current one, as of April 2016. The so-called 1958 Merlin Law, named after the Senator who proposed it, abolished state-regulated brothels and introduced a number of measures aimed at protecting those who operate in the sex industry. The tenets of the law, however,
} 
have become increasingly outdated and fail to reflect the much changed contemporary landscape of prostitution in the country (Crowhurst et al., forthcoming).

${ }^{4}$ All the translations of excerpts from the bills are mine.

${ }^{5}$ Interestingly, as mentioned in the previous footnote, the 1958 law that these bills intend to replace was aimed at freeing prostitutes from the oppressive systems of regulation and medical policing that the Italian state had introduced in the 1860 s - a very similar system to the one that these bills now want to reintroduce.

${ }^{6}$ Outdoor prostitution can indeed be dangerous, in Italy and elsewhere, often due to repressive antistreet prostitution policies (see, for example, Malucelli and Martin 2002; Maluccelli 2014; Ellison and Weitzer 2016). Nevertheless, to claim that all street sex workers are always exploited or forced by third parties is a hyperbole that contradicts the relatively limited research that has been conducted on this segment of the population. Equally hyperbolic and unsupported is the assertion that those who operate indoors always do so in better working conditions (McKeganey and Barnard 1996; Pitcher et al. 2006). 